\title{
BEOBACHTUNGEN ÜBER DIE ANPASSUNG VON VARROA JACOBSONI AN IHREN NATÜRLICHEN WIRT APIS CERANA IN SRI LANKA
}

\author{
Nikolaus KOENIGER ("), Gudrun KOENIGER (*), Noel H. P. WIJAYAGUNASEKARA (**)
}

Während Varroa jacobsoni als Parasit von Apis mellifera schwere Schäden verursacht, scheint ihr Verhältnis zu dem natürlichen Wirt Apis cerana wesentlich besser balanciert. Schäden bei $A$ pis cerana sind bisher nicht bekannt geworden. Die Frage nach der Ursache dieses Phänomens ist Gegenstand dieser Arbeit.

\section{MATERIAL UND METHODE}

Die Beobachtungen wurden in Sri Lanka vom Dezember 1980 bis März 1981 durchgeführt. Alle untersuchten Bienenvölker befanden sich im Anuradhapura -Distrikt (North-Central-Province).

Zur Diagnose wurden verdeckelte Arbeiterinnen- und Drohnenzellen geöffnet und die Puppe vorsichtig entfernt, wobei Varroa jacobsoni sowie ihre Jugendstadien festgestellt wurden. Insgesamt wurde an sieben Völkern Brutuntersuchung durchgeführt.

\section{ERGEBNISSE}

Die Ergebnisse der Brutdiagnose sind in Tab. 1 dargestellt. Bei allen sieben untersuchten Völkern wurde Varroa gefunden. Interessant ist der Unterschied zwischen

(*) Dept. of Env. Biology, Univ. of Guelph, Ontario, Canada N 1 G 2 W 1.

${ }^{(* *)}$ Dept. Agric. Zoology, Fac. of Agric., Univ. of Peradeniya, Sri Lanka. 


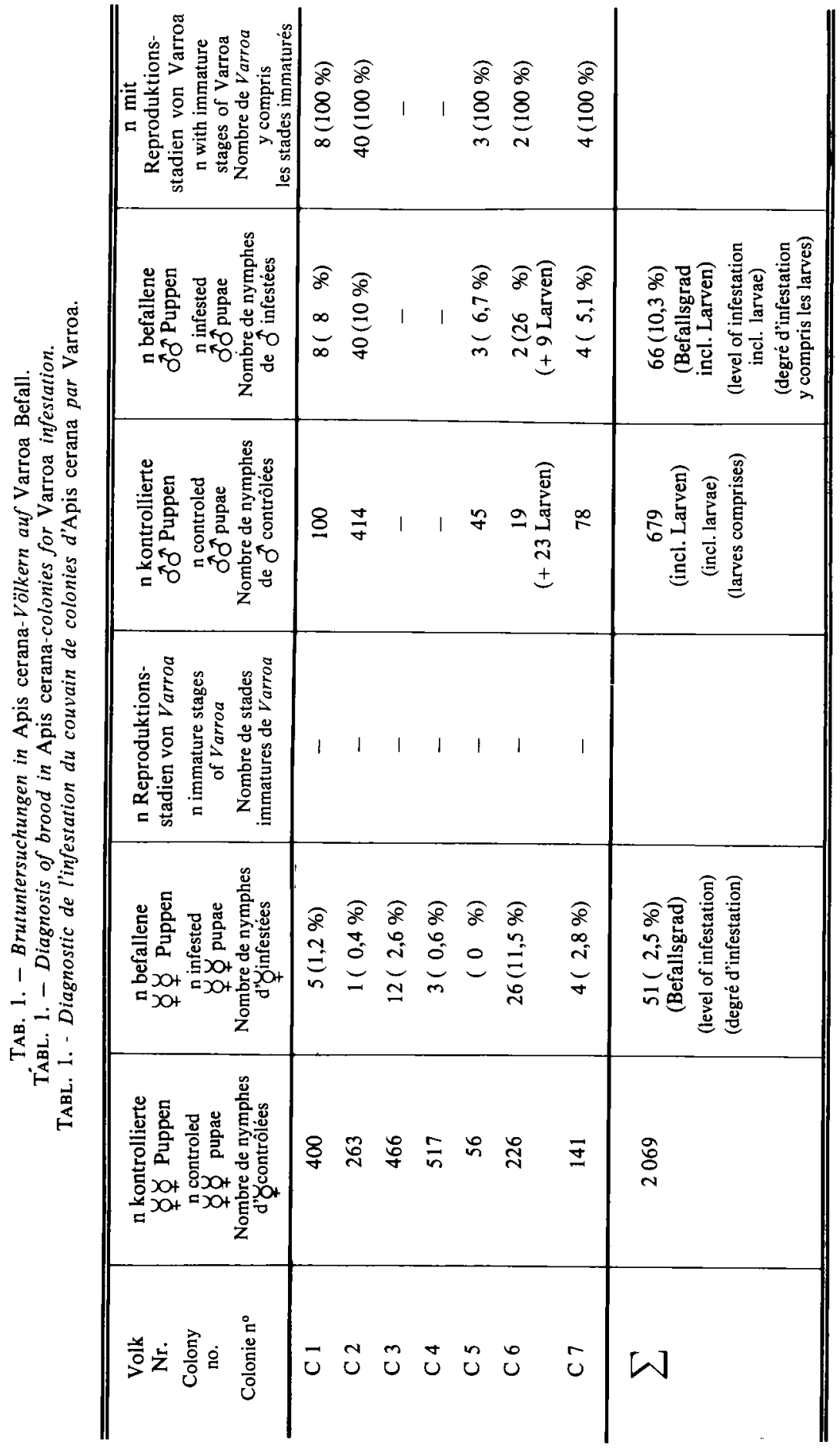


den auf Drohnenpuppen und den auf Arbeiterinnenpuppen gefundenen Milben. Während alle 66 Varroamilben in den Zellen mit Drohnenpuppen bereits in die Reproduktion eingetreten waren und in den Zellen Nymphen und z.T. junge $q q$ gefunden wurden, fanden sich in den Zellen mit Arbeiterinnen stets nur Varroaimagines ohne Jugendstadien. Dieser Befund ist statistisch signifikant. Er steht im Gegensatz zu den zahlreichen Beobachtungen an Apis mellifera, bei denen sich Varroa jacobsoni auch auf Arbeiterinnenbrut vermehrt. Es kann vermutet werden, dass die Beschränkung der Reproduktion von Varroa auf die Drohnenbrut bei Apis cerana in Sri Lanka eine auch für die Varroa unvorteilhafte Schädigung des Bienenvolkes verhindert. Dadurch wird der Befallsgrad der Cerana-Völker so gering gehalten, dass Varroa nicht bei den in den letzten Jahren intensivierten Imkerei in Sri Lanka gefunden wurde, sondern erst durch die hier beschriebene gezielte Diagnose.

Eingegangen im März 1981.

Reçu pour publication en mars 1981.

\author{
SUMMARY \\ OBSERVATIONS ON THE ADAPTION OF VARROA JACOBSONI \\ TO ITS NATURAL HOST APIS CERANA IN SRI LANKA
}

Varroa jacobsoni causes serious damage in colonies of Apis mellifera whereas nothing is known about similar effects in Apis cerana. This problem is the subject of our communication.

The observations were done from December 1980 to March 1981 in the Anuradhapura District (North Central Province, Sri Lanka). For diagnosis we opened capped brood cells and examined the pupa and the cell on Varroa and its larval stages.

The results of the diagnosis are given in Table 1. In all colonies we detected Varroa. Remarkable is the difference between the Varroae found on worker pupae and on drone pupae. Every of the latter mites had produced nymphs and young females. On the worker pupae we did not find any nymphs or eggs. This difference is statistically significant. In contrast to the behaviour of Varroa in Apis mellifera colonies, where the reproduction of Varroa takes place as well on worker brood as on drone brood, the reproduction of Varroa in cerana colonies is limited to the drone brood only. This seems to prevent severe damages of the infested cerana colonies and facilitate the coexistance of the parasite Varroa and its natural host Apis cerana.

\author{
RÉSUMÉ \\ OBSERVATIONS SUR L'ADAPTATION DE VARROA JACOBSONI \\ A SON HÔTE NATUREL APIS CERANA A SRI LANKA
}

Varroa jacobsoni cause de sérieux dégâts aux colonies d'Apis mellifica alors qu'on n'a relevé aucune action semblable sur Apis cerana. Ce problème est le sujet de notre communication. 
Les observations ont été faites de décembre 1980 à mars 1981 dans le district d'Anuradhapura (district du Centre-Nord, Sri Lanka). Pour diagnostiquer Varroa, nous avons ouvert des cellules de couvain operculé et examiné la présence de $V$. jacobsoni ou de ses stades larvaires sur les nymphes.

Les résultats du diagnostic sont présentés dans le tableau 1. Nous avons décelé Varroa dans toutes les colonies. Les Varroa présents sur les nymphes d'ouvrières sont très différents de ceux présents sur les nymphes de mâles. Les Varroa présents sur ces dernières ont donné des nymphes et de jeunes femelles. Sur les nymphes d'ouvrières nous n'avons trouvé ni nymphe, ni œuf de Varroa. Cette différence est statistiquement significative. Contrairement au comportement de Varroa dans les colonies d'Apis mellifica, où Varroa se reproduit aussi bien sur le couvain d'ouvrières que sur celui de mâles, la reproduction de Varroa dans les colonies d'Apis cerana est uniquement limitée au couvain de mâles. Ceci semble éviter de graves dégâts aux colonies cerana infestées et faciliter la coexistence du parasite Varroa et de son hôte naturel Apis cerana. 